\section{Upper Ludlowian-lower Pridolian stratigraphy, carbon isotope of the Timan-Northern Urals region}

TATIANA M. BEZNOSOVA - Institute of Geology Komi SC UB RAS, Syktyvkar - beznosova@geo.komisc.ru VLADIMIR A. MATVEEV - Institute of Geology Komi SC UB RAS, Syktyvkar • vamatveev@geo.komisc.ru LıouBov V. SOKOLOVA - Institute of Geology Komi SC UB RAS, Syktyvkar • sokolova@geo.komisc.ru Érkezett: 2018. 10. 11. " Received: 11. 10. 2018. - https://doi.org/10.14382/epitoanyag-jsbcm.2019.xx

\section{Abstract}

The paper presents the results of studying the geological structure of the Ludlowian boundary sediments and data on lithology, bio- and chemostratigraphy, and large-scale biotic reconstruction at the boundary Ludlow-Pridoli. The results obtained make it possible to draw a conclusion about the stratigraphic incompleteness of the Ludlow section in the Subpolar Urals and the interruption in sedimentation at the end of the Ludlow.

Keywords: brachiopods, ostracods, conodonts, Silurian, carbon isotope, events, boundary Ludlow-Pridoli, Timan-Northern Urals region, Russia

Kulcsszavak: pörgekarúak, kagylósrákok, konodonták, szilúri, karbon izotóp események, ludlovipridoli határa, Timan-Észak Ural régió, Oroszország
Tatiana M. BEZNOSOVA

Leading researcher at the laboratory of stratigraphy. Works at the N.P. Yushkin institute of Geology, Komi Science Centre, Ural Division, Russian Academy of Sciences, Syktyvkar (Russian Federation). Main fields of

her research interest are event stratigraphy, bio-chemostratigraphy, systematic, paleoecology and paleobiogeography brachiopods of the late Ordovician, Silurian and early Devonian TimanNorthern Urals region. She is author of 4 books and more than 150 scientific papers.

Vladimir A. MATVEEV Scientific employee in the laboratory of stratigraphy at the n N.P. Yushkin institute of Geology of the Komi SC UB RAS. Main fields of his research interest are stromatolite constructions of the Silurian of the Western slope of the Urals and the Chernov uplift. He is author of more than 30 scientific papers.

Lioubov. V. Sokolova Scientific employee in the laboratory of stratigraphy at the n N.P. Yushkin institute of Geology of the Komi SC UB RAS. Main fields of her research interest are biostratigraphy, systematic, paleoecology of the Silurian conodont Timan-Northern Urals region. She is author of more than 30 scientific papers.

\section{Introduction}

The evolutionary replacement of the brachiopods Didymothyris didyma (Dalman) and the Collarothyris canaliculata (Wenjukov), and the renewal of the taxonomic composition and a significant increase in the diversity of the biota observed in the characteristic lumpy limestones that form the bottoms of the Belushya stage of the Pridoli, is the basis of the paleontological study of the boundary Ludlow-Pridoli in Severouralsk region. The boundary Ludlow-Pridoli was adopted at the base of these lumpy limestones of the Belushya stage, in which the terrigenous or terrigenous-carbonate member is universally distinguishable, as reflected in the Ural stratigraphic scheme [1].

It should be noted that there is another point of view on the position of the boundary Ludlow-Pridoli in the Ural cuts, according to which this boundary lies above the carbonateterrigenous member, in the thickness of the lumpy limestones of the Belushya stage of the Pridoli [2].

The results of the newly conducted study of the boundary layers of the Ludlow-Pridoli in the Upper Silurian base section on the western slope of the Subpolar Urals, during which the previously unknown interval of the $16 \mathrm{~m}$ cut was uncovered, allow us to conclude that there is a break in the sedimentation that separates the Ludlow and Pridoli deposits.

The complexity of solving the problem of determining the boundary Ludlow-Pridoli in the North Urals region within the Mikhailovsky-Vaigach structural-facies zone is that the complex of brachiopods and other fauna characterizing stratotypic sections of the regional stages of Pridoli (Belushya and Karpov) do not contain species that are characteristic for Pridoli deposits in the global stratotype of the Czech Republic [1].

\section{Geological settings}

In the current structural-tectonic plan, the investigated section (236) lies within the Pre-Ural foredeep of the West Ural structural zone. Paleozoic deposits in this region belong to the Yelets (shelf) structural-formational zone and form natural outcrops, traced for more than $100 \mathrm{~km}$ along the right and left banks of the river Kozhym, and are confined to the periclinal closure of the Obeiz anticline (latitude $65^{\circ} 40^{\prime} 0.86^{\prime \prime} \mathrm{C}$, longitude $59^{\circ} 45^{\prime 2} 2.09^{\prime \prime}$ B) $[3,4]$.

\section{Materials and methods}

The interval of $24 \mathrm{~m}$ boundary Ludlow-Pridoli deposits considered here, in the terrigenous-carbonate section (236), chosen as the reference for the whole of the European NorthEast of Russia, is located on the western slope of the Subpolar Urals, on the Kozhym river (Fig. 1). The biostratigraphic separation of the Upper Silurian deposits in the Severouralsk region is based primarily on the zonal scale for brachiopods. Zonal dominant species have the narrowest stratigraphic and wide lateral ranges of distribution in Severouralsk region and beyond it (Fig. 2) [5].

The material for the article was presented by the authors' previously published brachiopod collections from the section 236, the published definitions of ostracods studied by A.F. Abushik and conodonts studied by S.V. Melnikov [6]. The definitions of brachiopods were made by T.M. Beznosova, vertebrates - by T. Märss and conodonts - by L.V. Sokolova and P. Männik. 

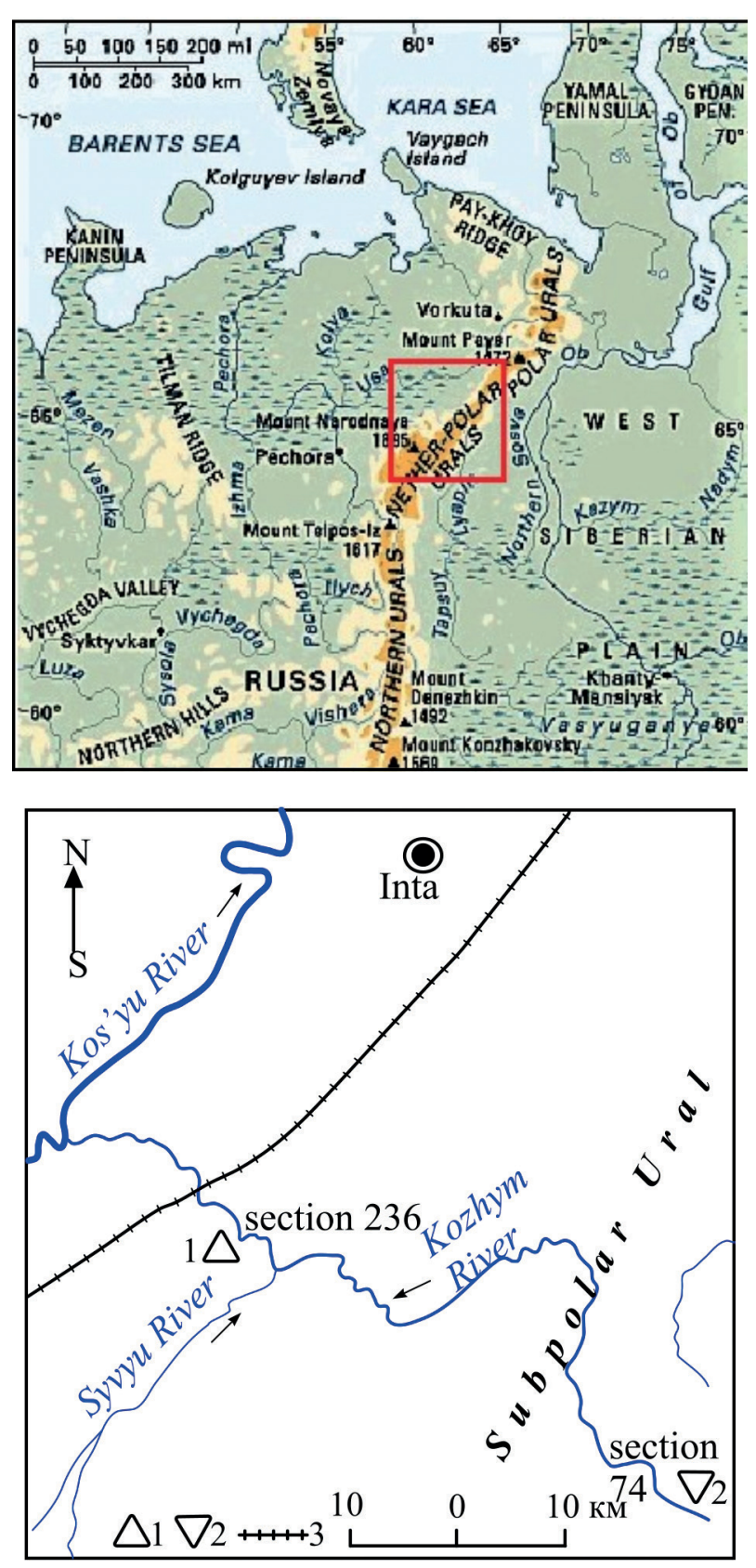

Fig. 1. Scheme of the location of the studied section in the Kozhym river basin (latitude N65'40'0.86", longitude E59 $\left.45^{\circ} 2.09^{\prime \prime}\right)$. Designations: (1) Polygnathoides siluricus (Branson and Mehl), (2) shell Pentamerid in the Reef Ecosystem, (3) railroad

1. ábra A vizsgált terület sémája a Kozhym folyó medencéjében (szélesség N6540’0.86", hosszúság E59²5’2.09”). Jelölések: (1) Polygnathoides siluricus (Branson és Mehl), (2) kagylóhéj Pentamerid a zátony ökoszisztémában, (3) vasútvonal

During the field work, P. Männik and V. Matveev carried out a layer-by-layer description of the section and made new collections - more than 100 rock samples and with the remains of fossil macrofauna, 22 samples for conodonts and other microfauna, 98 samples for the isotope $\delta 13 \mathrm{C}_{\text {carb }}$. Also, a previously uncovered interval of the Upper Ludlow section was uncovered, with a thickness of more than $16 \mathrm{~m}$.

The history of the study and the significance of the results of earlier studies of this section (236), selected as a reference for the Upper Silurian of the entire territory of the European North-East of Russia, are given in of monographs $[5,6,7]$.
Determination of the isotope $\delta 13 \mathrm{C}_{\text {carb }}$ in carbonate rocks was carried out at the Geonauka Center of the Institute of Geology, Komi Science Center, Uralian Division of the Russian Academy of Sciences, on the DELTA V Avantage mass-spectrometer (analyst I. V. Smoleva). The value of the isotopic coefficients was determined in ppm (\%o) by the standards PDB NBS18 and NBS19 (TS-limestone) for carbon. The error in determining both coefficients did not exceed $\pm 0.1 \%$. The isotope $\delta 13 \mathrm{C}_{\text {carb }}$ is determined in 98 samples (a sampling step of $50 \mathrm{~cm}$ ). All analytical works were carried out at the Institute of Geology, Komi Science Center, Uralian Division of the Russian Academy of Sciences named after academician N.P. Yushkin.

Collections are stored in the Museum of A.A. Chernov of the Institute of Geology, Komi Science Center, Uralian Division of the Russian Academy of Sciences named after Academician N.P. Yushkin (collection № 514 - lithological specimens and sections, № 368 - brachiopods, 693 - conodonts, № 654 - vertebrates).

\section{Results and discussion}

The late Ludlow (Ludlow) age of the Sizim stage determines the remains of the vertebrates Phlebolepis elegans Pander, pandemic conodonts Polygnathoides siluricus (Branson and Mehl) and brachiopods Didymothyris didyma (Dalman), which can be found in its sediments.

The sediments of the $15.5 \mathrm{~m}$ of the Upper Sizim stage are characterized by a gradual reduction in the taxonomic diversity of the biota, the disappearance of the Ludlowian brachiopods Didymothyris and the conodonts Adctenognathodus (Fig. 2). 10 genera of the ostracods of 18 disappear at the end of the Ludlow. The sedimentation signs of shallowing upwards along the section are clearly manifested - the alternation of limestones of stromatolitic, oolitic, microbial-clotting and dolomites with interlayers of flat-pebbled conglomerates, with cracks of desiccation, biomorphic, organogenic detritus, litho- and bioclasts with redeposited pebbles of limestone composition (Fig. 2.A). The maximum of the relative sea level falls on the end of the Ludlow. Reduction of the taxonomic diversity of fauna, replaced by the dominance of stromatolite-forming biota, observed in the section, indicates a major ecosystem restructuring at the end of the Ludlow (Fig. 2.B).

The upper boundary of the Ludlow Sizim stage was determined from the top of the interlayer of reddish-mottled clays, which fix the final regressive phase of the basin development at the end of the Ludlow and the characteristic features of the break in sedimentation (Fig. 2.C). [8, 9].

The transition from Ludlow to Pridoli deposits is lithologically fixed by a dolomite interlayer with large lithoclasts (break breccias, overlapping reddish-mottled clays) and thick lumpy dolomites with interbeds of calcareo-argillaceous black carbonaceous shaly mudstones corresponding to a new, transgressive sedimentation cycle. The transgression at the beginning of Pridoli facilitated the transportation and mass burial of organic matter at the base of the Belushya stage.

Paleontologically, this transition is characterized by a completely renewed composition of brachiopods [10] and ostracods [11]. The conodont complex of the lower part of the Belushya stage is mainly represented by the wide 


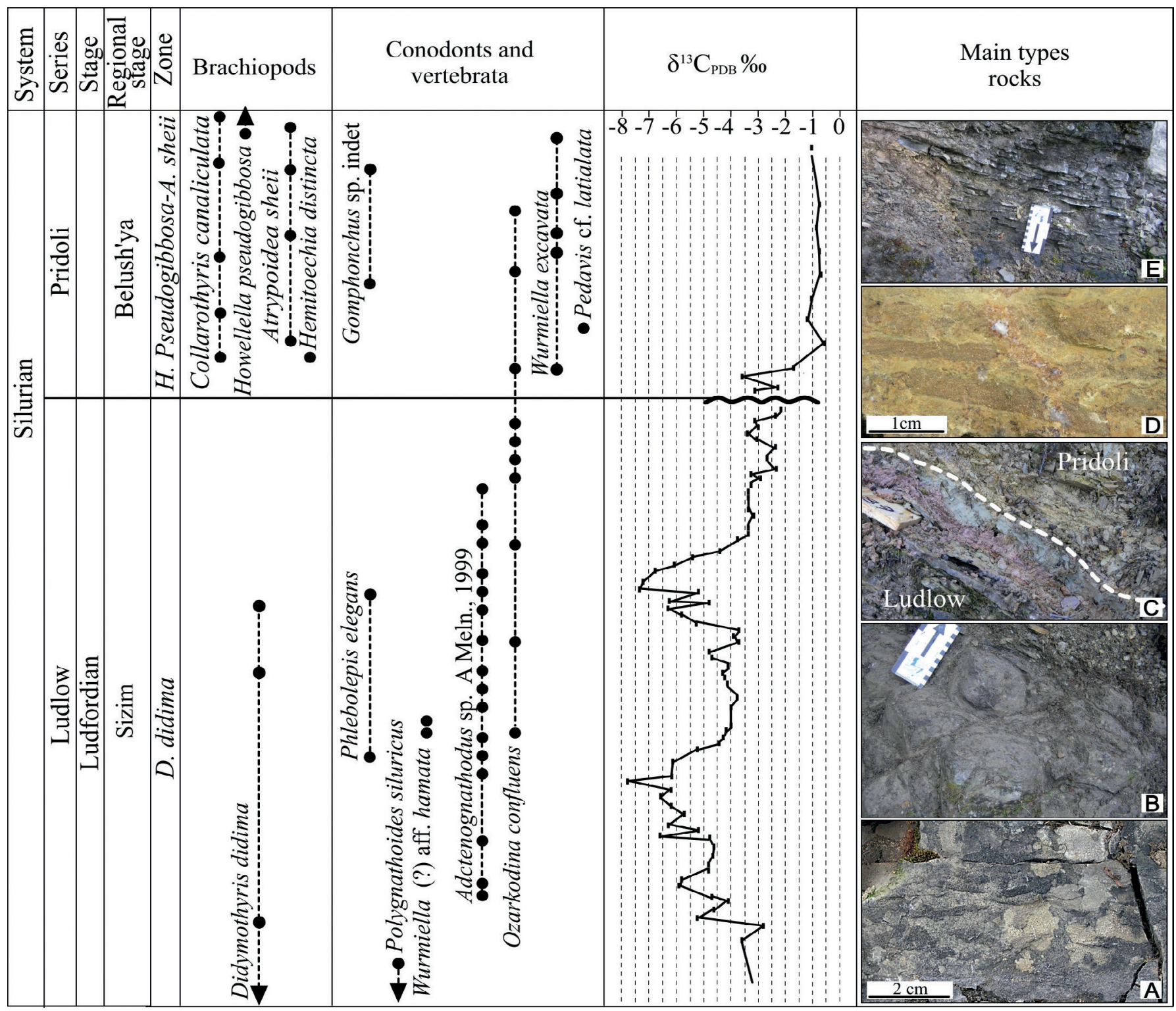

Fig. 2. Distribution of brachiopods, conodonts and vertebrates, isotopes $\delta 13 C_{\text {carb }}$ and lithological features in the boundary deposits of Ludlow and Pridoli on the Western slope of the Subpolar Urals (section 236). Designations: A- dolomites with interlayers of flat-pebbled conglomerates (layer 24, Sisim stage); B- shaped stromatolite buildups (layer 64, Sisim stage); C-ludlov and pridol border (layer 68); D- interlayer with coarse material layer 68a (Belushinsky stage); E- interlayering of black carbonaceous argillites, siltstones of limestone and cloddy limestones with brachiopods Hemitoechia distincta Nikiforova and Collarothyris canaliculata (layer 72, Belushinsky stage)

2. ábra Pörgekarúak, konodonták és gerincesek, izotóp $\delta 13$ C litológiai jellemzök a ludlovi-pridoli határán a szubpoláris Ural nyugati lejtöjén (szekció: 236). Jelölések: A-dolomitok lapos kavicsos konglomerátummal (réteg 24, Sisim stádium); B-alakos sztromatolit felépülések (réteg 64, Sisim stádium); C-ludlovi-pridoli határ (réteg 68); D- köztes réteg durva anyag réteggel 68 a (Belushinsky stádium); E- köztes réteg; fekete széntartalmú agyagpalák, iszapkövek, mészkövek és rögös mészkövek pörgekarúakkal (Hemitoechia distincta Nikiforova és Collarothyris canaliculata; réteg 72, Belushinsky stádium)

geographical distribution of Wurmiella excavata (Branson and Mehl), Ozarkodina confluens (Branson and Mehl), Pedavis cf. latialata (Walliser), Oulodus cf. siluricus (Branson and Mehl), Panderodus unicostatus (Branson and Mehl) [12] (Fig. 2).

The Belushya stage of Pridoli $(8.5 \mathrm{~m})$ in the same section (236) in the base is composed of limestone dolomites with large lithoclasts (break breccias), oriented along the bedding of rocks (Fig. 2.D). Above are the limestones with intercalations of black calcareous-carbonaceous shaly mudstones and greenishgray mudstones with the brachiopods of Hemitoechia distincta Nikiforova, which overlap limestones lumpy (Fig. 2.E) with brachiopods Collarothyriscanaliculata(Wenjukov), Atrypoidea sheii (Holtedahl), Howellella pseudogibbosa Nikiforova [5]. This shelly layer forms distinct marking brachiopod layers in the lower part of the Belushya stage, which can be traced in the sections of the Subpolar and Northern Urals, on the Chernov and Chernyshev uplifts, as well as numerous wells drilled on the territory of the Timan-Pechora oil and gas province. Similar layers with a complex of brachiopods, differing only in a large variety of representatives of the genus Atrypoidea, were first described by O.I. Nikiforova from the lower stratum of Pridoli of Vaigach island $[13,14]$. The complex of conodonts is represented mainly by species of wide geographical distribution and long-term existence of Wurmiella excavata (Branson and Mehl), Ozarkodina confluens (Branson and Mehl), Pedavis cf. latialata (Walliser), Oulodus cf. siluricus (Branson and Mehl), Panderodus unicostatus (Branson and Mehl). 


\subsection{The isotope $\delta 13 \mathrm{C}_{\text {carb }}$}

The isotopic characteristics of carbonates of the boundary Ludlow-Pridoli deposits in section 236 have shown that they are characterized by $\delta 13 \mathrm{Scarb}$ values, in range from -7.9 to $-1.8 \%$. Two intervals with sharp negative peaks $\delta 13 \mathrm{C}_{\text {carb }}$ in the section of the Upper Ludlow are distinguished on the isotope-carbon curve (Fig. 2).

The Pridoli part of the section is characterized by $\delta 13 \mathrm{C}_{\text {carb }}$ values from -3.6 to $-0.6 \%$. In the lower part of the Pridoli, a sharp shift of the curve from negative values of $\delta 13 \mathrm{C}_{\text {carb }}$ is recorded in the direction of positive values with an amplitude of oscillations of $3 \%$. Higher the values of $\delta 13 \mathrm{C}_{\text {carb }}$ are fairly constant. They are characterized by gradual weighting of the isotope $\delta 13 \mathrm{C}_{\text {carb }}$ to $-1.0 \%$, which determines the trend of the positive direction of the curve. The values of this interval fall on the layers of limestones with characteristic lumpy detachment enclosing diverse fauna of Pridoli age (Fig. 2).

Thus, the curve of the isotope $\delta 13 \mathrm{C}_{\text {carb }}$ lies in the region of negative values of $\delta 13 \mathrm{C}_{\text {carb }}$ with two negative excursions. The sharp decreases of $\delta 13 \mathrm{C}_{\text {carb }}$ in the first and second interval (down to $-7.9 \ldots-7.4$ ) indicate significant changes in the characteristics of the sedimentation environment in TimanNorthern Urals marine basin.

Thus, the boundary Ludlow-Pridoli is determined by the contact of variegated clays and dolomites with large and lithoclasts (break breccias), above which dark gray lumpy limestones with interlayers of black carbonaceous and greenish-gray mudstones lie.

The major ecosystem restructuring associated with the Lower Pridolian Event is traced in sections in the North-East of Eurasia, the Arctic islands of Russia (Vaigach, N. Zemlya, Dolgiy) and Canada, Alaska [15, 16, 17, 18, 19].

\section{Conclusions}

The obtained results indicate the global character of the biotic rearrangements at the end of the Ludlow and at the very beginning of the Pridoli, the traces of which were preserved in the reference section of the Upper Silurian in the Subpolar Urals.

The decline in sea level, the widespread development of stromatolite-forming biota, the reduction of biodiversity, the disappearance of conodonts of the genus Adctenognathodus at the end of the Ludlow and the change in the dominants in the biota at the beginning of the Pridoli reflect the general response of organisms of different hierarchies (brachiopods, ostracods, conodontophorides and microbials) to habitat conditions late Ludlow and at the boundary Ludlow-Pridoli in TimanNorthern Urals marine paleobasin. The significant shallowing of Timan-Northern Urals marine basin at the end of Ludlow caused the death of a large mass of microbial communities, as well as abundant and diverse biota of the Ludlow reefs.

\section{Acknowledgements}

The authors are grateful to P. Männik for joint study of the section, T. Märss for the determination of vertebrate remains, A.V. Zhuravlev for valuable advice and comments, and to I.V. Smoleva, engineer of the Geonauka Center of the Institute of Geology of the Komi Science Center, Uralian Division of the Russian Academy of Sciences, for the determination of the isotope $\delta^{13} \mathrm{C}_{\text {carb }}$ in carbonate rocks.

\section{References}

[1] Antsygin, N. Ya. (1994): Explanatory note to Ural stratigraphic maps. Nauka Publishers, Ekaterinburg, 95 p.

[2] Modzalevskaya, T. L. - Marss, T. (1991): On the age of the lower boundary of the Greben Regional Stage of the Urals. Proceedings of the Estonian Academy of Sciences. Geology. Vol. 40, No. 3, pp. 100-103.

[3] Puchkov, V. N. (2010): Geology of the Urals and Cis-Urals (actual problems of stratigraphy, tectonics, geodynamics and metallogeny). Design Poligraph Service, Ufa. 280 p.

[4] Yudin, V. V. (1994): Orogenez Severa Urala i Pay-Khoya. Nauka Publishers, Ekaterinburg. 286 p.

[5] Beznosova, T. M. (2008): Brachiopod communities and biostratigraphy of Upper Ordovician, Silurian and Lower Devonian of North-Eastern margin of Baltia paleocontinent. Nauka Publishers, Ekaterinburg, 218 p.

[6] Opornye razrezy verkhnego ordovika I nizhnego silur Pripolyarnogo Urala (Upper Ordovician and Silurian outcrops of Subpolar Ural). Komi filial AN SSSR, 1987, $34 \mathrm{p}$.

[7] Modzalevskaya, T. L. (1985): Silurian and the Early Devonian brachiopods from the European part of the USSR. Order Atiridida. M., 128 p.

[8] Matveev, V. A. - Kanev, B. I. (2016): Features of the upper Ludlow deposits in the Silurian key section on the western slope of the Subpolar Urals. Vestnik of Institute of Geology of Komi SC UB RAS. No. 8, pp. 3-8. https://doi.org.10.19110/2221-1381-2016-8-3-8

[9] Kanev, B. I. - Beznosova, T. M. - Matveev, V. A. - Gömze, L. A. (2017): Environment changes at the Ludlow and Pridoli boundary (Subpolar Urals). Épitöanyag - Journal of Silicate Based and Composite Materials, Vol. 69, No. 4. pp. 132-133. https://doi.org./10.14382/epitoanyag-jsbcm.2017.24

[10] Beznosova, T. M. (2000) Silurian brachiopods in the Timan-norhtern Ural region: zonation and palaeoecology. Proceedings of the Estonian Academy of Sciences, Geology, Vol. 49, pp. 126-146.

[11] Abushik, A. (2000): Silurian-earliest Devonian ostracode biostratigrahy of the Timan-Norhtern Ural region, Proceedings of the Estonian Academy of Sciences, Geology, Vol. 49. pp. 126-146

[12] Beznosova, T. M. - Matveev, V. A. - Sokolova, L. V. - Kanev B. I. (2017): Regional manifestation of the global Ludford event (Lau Event) in the section of the Western slope of the Subpolar Urals. Geodynamics, substance, ore genesis of the East European Platform and its folded framing: Extended abstract of scientific conference reports. Syktyvkar: IG Komi SC UB RAS. pp. 19-21.

[13] Cherkesova, S. V. (1970): Silurian Greben stage of the island Vaigach. Stratigraphy and fauna of Silurian deposits of Vaigach. Proceedings of the Scientific Research Institute of Geology of the Arctic, pp. 4-24.

[14] Nikiforova, O. I. (1970): Brachiopods of Greiben stage of the island Vaigach (Late Silurian). Stratigraphy and fauna of Silurian deposits of Vaigach. Proceedings of the Scientific Research Institute of Geology of the Arctic, pp. 97-149.

[15] Baranov, V. V. - Blodgett, R. B. (2013): Correlation of the Pridolian beds (upper Silurian) of the Arctic regions of Eurasia and North America. Otechestvennaya geologiya. No. 5, pp. 52-57.

[16] Baranov, V. V (2015): Global events Lower Pridolsky and Klonk in the Middle Paleozoic in the northeast of Eurasia and in adjacent territories. Nauka i obrazovaniye. No. 3 (79). pp. 33-37.

[17] Jeppsson, L. (1998): Silurian oceanic events. A summary of general characteristics. In: Landing, E., Johnson, M.E. (Eds.), Silurian Cycles: Linkages of Dynamic Stratigraphy with Atmospheric, Oceanic and Tectonic Changes, James Hall Centennial Volume, New York State Museum Bulletin, Vol. 491, pp. 239-257.

[18] Jones, B. (1997): Variation in the upper Silurian brachiopod Atrypella phoca (Salter) from Somerset and Prince of Wales island, Arctic Canada. Journal of Paleontology, Vol. 51, No. 3, pp. 459-479.

[19] Nekhorosheva, L. V. - Patrunov, D. K. (1981): Greben stage of the Island Vaygach-Novaya Zemlya region. Sovietskaya Geologiya. No. 4, pp. 80-85.

$\underline{\text { Ref.: }}$

Beznosova, Tatiana M. - Matveev, Vladimir A. - Sokolova, Lioubov V.: Upper Ludlowian-lower Pridolian stratigraphy, carbon isotope of the Timan-Northern Urals region Építőanyag - Journal of Silicate Based and Composite Materials, Vol. 71, No. 1 (2019), 24-27.p. https://doi.org/10.14382/epitoanyag-jsbcm.2019.5 